\title{
LIIKUMISSÜNDMUSED EESTI KEELE ÕPPIJATE KIRJALIKES NARRATIIVIDES
}

\author{
Raili Pool ja Renate Pajusalu \\ Tartu Ülikool
}

Kokkuvõte. Artiklis käsitletakse vene emakeelega eesti keele õppijate (keeleoskustase B2) kirjalikes narratiivides esinenud liikumissündmusi. Materjaliks on M. Mayeri (1969) sõnadeta pildiraamatu "Frog, where are you?" järgi kirjutatud narratiivid. Põhimaterjal pärineb 21-lt vene emakeelega üliõpilaselt ning võrdlusmaterjal 21-lt eesti emakeelega üliõpilaselt. Õppijarühmalt on analoogiline tekstimaterjal kogutud ka nende emakeeles vene keeles. Liikumissündmuste analüüsimisel lähtutakse L. Talmy $(1985,2007)$ käsitlusest. Kitsamalt keskendutakse liikumissündmuste kirjeldamisel kasutatud verbidele ja verbisatelliitidele, liikumise lähte- ja sihtkoha väljendamisele ühe ja sama liikumissündmuse kirjeldamisel ning vaadeldakse suhtlusstrateegiate rakendamise võimalusi õppijarühma narratiivides. Analüüsitud keeleainese põhjal võib väita, et liikumisnarratiivi etappe eesti keele õppijad ei väldi. Samas kasutavad nad väga sageli üldise tähendusega liikumisverbe minema ja tulema, mis võimaldavad edasi anda piltidel kujutatud tegevuse dünaamikat, kuid milles ei sisaldu liikumisviis. Liikumise teed väljendavate verbisatelliitide (afiksaaladverbide) kasutamine ei ole vene emakeelega õppijatele raske. Kuna eesti keele afiksaaladverbid ja vene keele verbiprefiksid on funktsionaalselt sarnased, on tõenäoline, et õppijad on toetunud vene keele verbiprefiksite analoogiale. Vene üliõpilaste narratiive iseloomustab ka liikumise lähte- ja sihtkoha sage liitmine ühe ja sama liikumissündmuse kirjeldusse ning staatilise olema-verbi kasutamine liikumise kirjeldamisel. Viimane on käsitatav õppijatele omase ümberütlemisstrateegiana ning eesti võrdlusrühma narratiivides ei esine.

Märksõnad: liikumissündmus, verbisatelliidid, afiksaaladverbid, suhtlusstrateegiad, vene keel, eesti keel

\section{Sissejuhatus}

Liikumine on üks inimkeele ja -tunnetuse baasvaldkondi. Laps alustab keele omandamist keha ja ruumi ning ruumis liiku- 
mise mõistmise ja väljendamisega ${ }^{1}$. Teise keele õppija on nende valdkondade baasmudelid juba oma emakeelega kaasa saanud ja seega tuleb tal teist keelt omandades see juba varem olemasolevasse tunnetuslikku raamistikku paigutada. Dan Slobin (1996a) väidabki oma thinking for speaking-hüpoteesis, et esimest keelt omandades õpib laps teatud viisil mõtlema, mis omakorda avaldub keelekasutuses, muuhulgas ka liikumissündmustest rääkides. Eelkõige mõjutab liikumissündmuse erinev keelendamine seda, milline informatsioon on esitatud taustana (ingl backgrounded information) ja milline esilduvana (ingl foregrounded, vt nt Cadierno 2008: 245).

Leonard Talmy $(1985,2007)$ järgi on keeltevahelised erinevused liikumissündmuste väljendamisel väga suured ning tüpoloogiliste erinevuste järgi eristab ta nn satelliidikeeli ja verbikeeli. Satelliidikeeltes on põhiverbis ühendatud LIIKUMINE ja LIIKUMISVIIS/PÕHJUS ning TEED väljendatakse eraldi satelliidi abil, milleks on verbipartiklid ja verbiprefiksid. Satelliidikeelte hulka kuuluvad nt hiina keel ja indoeuroopa keeled (sh vene keel), v.a romaani keeled. Verbikeeltes on verbitüves ühendatud LIIKUMINE ja TEE ning LIIKUMISVIISI ja PÕHJUST väljendatakse eraldi adverbiaalide või gerundiivide abil, verbikeelte hulka kuuluvad nt romaani keeled. Eesti keelele iseloomulikuks jooneks on võimalus väljendada verbitüvega ühtaegu nii LIIKUMIST kui ka LIIKUMISVIISI (nt jooksma, hüppama) ning liikumise TEE tüüpiline väljendamine afiksaaladverbide abil (nt välja ronima, alla viskama). Kuigi eesti keeles esineb ka verbikeeltele omaseid väljendusvõimalusi (nt väljus majast joostes), kuulub see Talmy tüpoloogia järgi pigem satelliidikeelte hulka, satelliitidena käsitletakse sel juhul eesti keele afiksaaladverbe (Veismann ja Tragel 2008). Seega on eesti ja vene keel Talmy liigituse järgi sama tüüpi keeled, kuid see ei tähenda, et nad väljendaksid liikumissündmusi täiesti identselt. Põhiline erinevus on see, et 1) eesti afiksaaladverbidele vastavad enamasti vene keele prefiksid ja 2) eesti keeles võivad SIнтконт ja LÄнтЕКонт olla väljendatud

1 Ülevaadet ruumisõnade omandamisest ja omandamise erinevustest eri keeltes vt nt Dabrowska 2004: 83-105. 
kas käände- või adpositsioonikonstruktsiooni kaudu (lauale või laua peale), vene keeles sellist valikut pole ja tegemist on alati prepositsioonifraasiga.

Kui õppija emakeel on sihtkeelest tüpoloogiliselt (kas või mõnes aspektis) erinev, võib emakeeles mõtlemine mõjutada (liikumis)sündmuste kirjeldamist õpitavas keeles. Selliseid tulemusi on saanud nt Teresa Cadierno (2004; vt ka Cadierno ja Ruiz 2006), kes võrdles liikumissündmuste väljendamise seisukohast taani emakeelega hispaania keele õppijate hispaaniakeelseid narratiive hispaania keelt emakeelena kõnelejate analoogiliste narratiividega. Cadierno (2004) uurimus näitas, et õppijad võivad oma emakeelest lähtuvalt valida õpitavas keeles hoopis keerulisema väljendusvõimaluse kui emakeelekõnelejad, püüdes liikumissündmuste kirjeldamisel oma emakeelest taani keelest tuttavaid verbisatelliite tuua ka hispaania keelde, milles verbikeelena on satelliidikasutus väga piiratud.

Siinses artiklis uurimegi, kas ja kuidas erineb eestlaste ja eesti keele venekeelsete õppijate verbide ja afiksaaladverbide kasutus liikumissündmuste väljendamisel; muud aspektid jäävad esialgu vaatluse alt välja. Oletame, et erinevused tulenevad vähemalt kahest asjaolust: eesti ja vene keele erinevustest ning õppijakeele üldistest eripäradest. On ju selge, et mitte kõik õppijakeele eripärad ei tulene interferentsist, vaid oma roll on ka lihtsalt puudulikul sihtkeele oskusel. Keeleõppija võib oma keeleliste ressursside puudulikkust korvata sellega, et kasutab ainult või valdavalt väheseid hästi omandatud konstruktsioone.

Artikli konkreetsemad uurimisküsimused on:

- milliseid verbe vene emakeelega eesti keele õppijad kirjalikes narratiivides liikumissündmuste väljendamisel kasutavad ja mil viisil nende verbikasutus erineb emakeelekõnelejate omast;

- kuidas kasutavad vene emakeelega õppijad liikumistee väljendamiseks eesti keele afiksaaladverbe ja kas see erineb eestlaste kasutusest;

- kuidas vene emakeelega eesti keele õppijad ühe liikumissündmuse kirjeldamisel liikumise lähte- ja sihtkohta väljendavad; 
- kas ja kuidas kasutavad keeleõppijad liikumissündmuste kirjeldamisel kirjalikes narratiivides abistavaid suhtlusstrateegiaid, st mida õppija teeb, kui ta end päris täpselt väljendada ei oska (nt kas kirjeldab liikumist ümberütlevalt, ilma liikumisverbide kasutamiseta vms).

\section{Materjal ja meetod}

Analüüsitav keeleaines on kogutud Mercer Mayeri sõnadeta pildiraamatu "Frog, where are you?" (Mayer 1969) järgi kirjutatud narratiividest, nn konnalugudest. Nimetatud raamat on rahvusvahelises lingvistikas laialdaselt kasutatav stiimul liikumissündmuste väljendamise uurimiseks (nt Slobin 1996a, Slobin 1996b, Berman ja Slobin 1994; teise keele omandamise uurimisel ka nt Cadierno 2004, Cadierno ja Ruiz 2006). Raamat sisaldab kokku 24 pilti, mis on omavahel loogiliselt seotud ning millel kujutatud sündmused on dünaamilised. Pildisari kujutab väikest poissi, kelle konn põgeneb purgist ning keda poiss koos oma koeraga seejärel metsa otsima läheb, kohtudes oma otsingutel erinevate loomadega.

Artiklis käsitletav uurimismaterjal pärineb 21-lt vene emakeelega üliõpilaselt, kes ainestiku kogumise hetkel valdasid eesti keelt vähemalt B2-tasemel ${ }^{2}$, võrdlusrühmaks on 21 eesti emakeelega üliõpilast. Kõik uurimuses osalenud õppisid Tartu ülikoolis, vene emakeelega üliõpilased eesti keele ja kultuuri muukeelsetele erialal, eesti üliõpilased eesti ja

2 B2 ehk iseseisva keelekasutaja taset kirjeldatakse Euroopa Nõukogu kuueastmelisel keeleoskustasemete üldskaalal järgmiselt (Hausenberg jt 2008: 21): „Iseseisev keelekasutaja mõistab keerukate abstraktsel või konkreetsel teemal tekstide ning erialase mõttevahetuse tuuma. Suudab spontaanselt ja ladusalt vestelda sama keele emakeelse kõnelejaga. Oskab paljudel teemadel luua selget, üksikasjalikku teksti ning selgitada oma vaatenurka, kaaluda kõnealuste seisukohtade tugevaid ja nõrku külgi." Käesolevas uurimuses osalejad olid vene õppekeelega gümnaasiumi lõpus edukalt sooritanud eesti keele kui teise keele riigieksami, mis on tasemelt võrdsustatud B2-taseme eksamiga. 
soome-ugri keeleteaduse erialal. Ainestik on kogutud 2010. a kevadel ${ }^{3}$.

Uurimuses osalejatele anti pildiseeriad, paluti esmalt pildid algusest lõpuni läbi vaadata, et saada ettekujutus, millest see lugu räägib, ning seejärel kirjutada eesti keeles piltide abil lühijutuke. Mõlemale rühmale anti kirjutamiseks aega 45 minutit. Aeg oli ülesande täitmiseks piisav, mõned üliõpilased said ülesande kiiremini valmis. Vene emakeelega rühmale anti ette ka ülesande täitmiseks tarvilike nimisõnade loend (nt hirv, järsak, öökull jne), mida paluti oma jutustuses kasutada. Verbiloendit õppijatele ette ei antud ning sõnaraamatut ega muid abivahendeid kirjutamise ajal kasutada ei saanud. Eesti rühmale nimisõnade loendit ette ei antud. Kummagi rühma üliõpilased ei teadnud, mida nende kirjatööde alusel täpsemalt uurima hakatakse, seega ei pööranud nad eelduste kohaselt liikumise väljendamisele kõrgendatud tähelepanu.

Samadelt vene emakeelega õppijatelt koguti umbes kaks nädalat hiljem sama pildiseeria järgi kirjutatud narratiivid ka nende emakeeles. Neid tekste kasutatakse käesolevas artiklis ainult võrdlusmaterjalina, põhjalik eesti- ja venekeelsete narratiivide liikumissündmuste kontrastiivne analüüs ei ole siinse kirjutise eesmärk.

\section{Liikumissündmuse olemus ja selle komponendid}

Liikumissündmuste analüüsimisel on aluseks võetud Leonard Talmy $(1985,2007)$ liikumissündmuste käsitlus. Liikumissündmus on Talmy (2007: 70-71) järgi situatsioon, mis sisaldab füüsilise entiteedi liikumist või püsiva koha säilitamist ehk teiste sõnadega öeldes, liikumissündmusena võib käsitada nii kulgevat

3 Mayeri (1969) pildiraamatut on liikumissündmuste väljendamise uurimise jaoks materjali kogudes varem kasutanud ka Tartu ülikooli üliõpilased Marje Koiksaar (kirjalikud L2 narratiivid) ja Jaana Seinberg (2011) (suulised L1 narratiivid) oma bakalaureusetöödes. Siinse artikli kirjutamise ajal ei olnud need tööd veel valmis. 
(ese muudab oma asukohta) kui ka mittekulgevat liikumist (ese säilitab oma põhilise asukoha). Käesolevas artiklis vaatleme ainult selliseid liikumissündmusi, milles LIIKUJA tõesti vahetab asukohta või asendit. Liikumissündmuse peamised komponendid Talmy järgi on LIIKUJA (liikuv või liigutatav entiteet), TAUST (siia kuuluvad liikumise LÄHTEKOHT, ASUKOHT ja SIHTKOHT), TEE (kurss, mida LIIKUJA järgib, on seotud taUSTAGA) ning LIIKUMINE (hõlmab ka LIIKUMISviIsI ja PÕHJUSE). Talmy (ibid.) käsitleb liikumissündmusena ühe LIIKUJA ühekordset asukoha muutmist või säilitamist teise objekti ehk TAUSTA suhtes. Mayeri (1969) konnalugude pildiseeria kujutab poisi ja koera rännakut kodust läbi metsa tiigini, milles kodu võib tinglikult pidada mitmest etapist koosneva pikaajalise liikumise LÄHTEKOHAKS ja tiiki sІнтKOHAKS. Varasemad konnalugude materjalil põhinevad uurimused (nt Cadierno 2004, Cadierno ja Ruiz 2006) ei käsitle konnalugu tervikuna ühe liikumissündmusena, vaid piiritlevad liikumissündmuse ühe predikaati sisaldava osalausega. Ka siinses artiklis käsitleme konnalugu tervikuna kui üht liikumisnarratiivi, mis koosneb paljudest järjestikustest liikumissündmustest. Liikumissündmuses osaleva entiteedi rolli täpsemaks kirjeldamiseks kasutame LIIKUJA kõrval ka LIIGUTAJA ja LIIGUTATAVA rolle.

Käesoleva uurimuse eesti keele õppijate emakeeles vene keeles väljendatakse liikumise TEED peamiselt verbiprefiksitega (nt vyxodit'), eesti keeles verbipartiklitega, milleks on afiksaaladverbid (nt välja tulema), ning Talmy tüpoloogia järgi võib nii eesti kui vene keelt lugeda satelliidikeelte hulka kuuluvaks. Nagu juba mainisime, on eesti ja vene keele verbisatelliitide vahel funktsionaalne keeltevaheline sarnasus: nii eesti keele afiksaaladverbid kui ka vene keele verbiprefiksid võimaldavad liikumissündmuses muu hulgas edasi anda liikumise TEED, erinevus on satelliitide paiknemises. Lähte- ja sihtkeele sarnasused on teise keele omandamisel määrava tähtsusega ning keelte sarnasus on lähtekeele positiivse mõju alus, seda ka mittesugulaskeelte puhul (Ringbom 2007: 7-9, 24-26). Seega võib eeldada, et oskus tuua paralleele vene keele verbiprefiksite ja eesti keele afiksaaladverbide kasutamise vahel on õppijarühmale liikumissündmuste sihtkeelepärasel väljendamisel toeks. 


\section{Liikumissündmuste väljendamine eesti keelt teise keelena õppijate kirjalikes narratiivides}

\subsection{Narratiivide pikkus ja liikumissündmuste määratlemine}

Artiklis analüüsitav keeleaines jaguneb kolme rühma: uurimuse põhimaterjali moodustavad vene üliõpilaste eestikeelsed tekstid (keelenäidete juures tähistatakse need järgnevalt lühendiga L2), võrdlusmaterjaliks on eesti üliõpilaste eestikeelsed (L1 eesti) ning vene üliõpilaste venekeelsed tekstid (L1 vene). Vene üliõpilaste eestikeelsete tekstide keskmine pikkus on 314 sõna, eesti üliõpilastel 372 sõna ning vene rühma venekeelsetes tekstides 289 sõna. Erinevus eestikeelsete L1 ja L2 narratiivide keskmises pikkuses on ootuspärane ning sarnaneb Cadierno (2004) samalaadse uurimuse tulemustega: ka tema uurimuses osutusid sama meetodi alusel kogutud narratiividest L1 tekstid (hispaania keel emakeelena) pikemaks kui L2 tekstid (taanlastest hispaania keele õppijad). See on loomulik tulemus, kuna emakeeles väljendatakse end vabamalt ja keelelisi vahendeid on rohkem. Siinse uurimuse tulemused erinevad Cadierno (2004) omadest õppijarühma emakeeles kirjutatud tekstide pikkuse osas: Cadierno materjalis paigutusid õppijate emakeeles (taani keeles) kirjutatud konnalood sõnade arvult teisele kohale, meie uurimuses aga on venelaste venekeelsed tekstid kolmest materjalikogust kõige lühemad.

Meie vene emakeelega üliõpilased on seega loonud oma emakeeles mõnevõrra lühemaid tekste kui teises keeles. Kindlaid põhjusi selleks pole kerge leida. Osaliselt tingib erinevusi sõnade üldarvus eesti ja vene keele erinev struktuur, näiteks verbisatelliitide paiknemine. Eesti keeles vormistatakse põhiverb ja afiksaaladverb eraldi sõnadena (nt ronis välja), vene keeles aga moodustab verbiprefiks põhiverbiga ühe terviku (nt vyskočil). Kuna uuritavates narratiivides sisaldub rohkesti verbisatelliite, on võimalik, et see struktuurierinevus on sõnade arvu mõjutanud. Samas loeb Wordi programm eraldi sõnadeks ka prepositsioonid, mida vene keeles kasutatakse käändefunktsioonide väljendamiseks juhtudel, kus eesti keeles moodustab käändelõpp 
sõnatüvega ühe terviku (nt vn vyskočil iz banki, ee ronis purgist välja - mõlemas fraasis on kolm sõna). See asjaolu vähendab verbisatelliitide mõju sõnade arvule ning eesti ja vene keele struktuuri erinevused ei põhjenda venekeelsete tekstide lühidust piisavalt. Võib arvata, et põhjus on tegelikult selles, et keeleõppijad kirjutasid sama pildiseeria alusel narratiivi kaks korda - esimene kord eesti keeles ja paari nädala pärast vene keeles. Teisel korral oli teema neile juba tuttav ning üks kord läbi mõeldud ja kirjutatud, mistõttu väljenduti ökonoomsemalt. Täielikult välistada ei saa ka seda, et samal teemal teist korda kirjutades tunti mõningast tüdimust ja püüti ülesanne kiiremini lõpetada.

Käesoleva uurimuse seisukohast on oluline, kas vene ja eesti üliõpilaste tekstides esines liikumissündmuste kodeeringuid võrreldaval hulgal. Liikumissündmuste määratlemiseks otsisime tekstidest välja kõik liikumissündmust väljendavad osalaused. Tekstid sisaldasid ka rohkesti lauseid, milles liikumissündmusi üheski osalauses ei kirjeldata (näide 1).

(1) Konnad aga istusid rõõmsalt puutüvel ja vaatasid poisile ja koerale rahuliku hingega tagant järgi. (L2)

Näited 2-4 illustreerivad lauseid, milles on fikseeritud üks või mitu liikumissündmuse kodeeringut.

(2) Öösel, kui poiss ja koerake rahulikult magasid, põgenes Fred oma purgist. (L1 eesti)

(3) Jaan ja Lontu kukkusid ojja. (L2)

(4) Hirv tõusis püsti ja poiss sattus hirve peale. (L2)

Näites 2 on kaks osalauset, kuid liikumissündmuse väljendajaks on liigitatud ainult viimane (põgenes Fred oma purgist), näites 3 väljendab lause tervenisti üht liikumissündmust ning näites 4 on määratletud kaks liikumissündmuse kodeeringut (hirv tõusis püsti, poiss sattus hirve peale ${ }^{4}$ ).

4 Osalause poiss sattus hirve peale on selle kirjutanud õppija terviknarratiivi arvestades kindlasti liikumissündmuse kirjeldus, väljendades poisi asukoha muutumist. Selles lauses on peale kaassõna, mitte afiksaaladverb ühendverbi (kellelegi) peale sattuma koosseisus. 
Liikumissündmustena ei ole arvesse võetud liikumisverbide kasutamist ülekantud tähenduses (näited 5 ja 6 ).

(5) ... aga aeg jooksis ... (L2)

(6) Möödus veidike aega ... (L1 eesti)

Eestikeelsetest L1 narratiividest on identifitseeritud kokku 464, L2 tekstidest 446 ning venekeelsetest 460 liikumissündmuse kodeeringut. Keskmiselt esines eestikeelsetes L1 tekstides 22, L2 tekstides 21 ning venekeelsetes tekstides 22 liikumissündmuse kodeeringut ühe teksti kohta. Analüüsi aluseks olevad L1- ja L2-kõnelejate narratiivid on omavahel liikumissündmuste väljendamise osas võrreldavad ning erinevused tekstide keskmises pikkuses ei ole mõjutanud liikumise kirjeldamist. Eesti üliõpilaste narratiivide suurem üldine sõnade arv tuleb selle arvelt, et pikemalt on esitatud liikumist mittesisaldavaid tegelaste kirjeldusi, nende iseloomu ja tausta, mõnel juhul ka dialoogilist teksti. Õppijad seevastu ei ole pidanud enamasti vajalikuks lisada oma jutustusele ilukirjanduslikku mõõdet ja on püüdnud edasi anda eeskätt piltidel nähtavat tegevust.

\subsection{Liikumissündmuste väljendamisel kasutatud verbid}

Järgnevalt on vaatluse all verbid, mis esinesid L2 ja L1 narratiivides liikumissündmuste väljendamisel. Tekstides oli veel muidki verbe, kuid väljaspool liikumissündmuste kirjeldusi esinenud verbe siin ei käsitleta.

L2 narratiivides esines liikumissündmusi väljendavates osalausetes kokku 63 eri verbi, L1 narratiivides 116 eri verbi. Üheks verbiks on loetud verbitüvi, sõltumata selle juurde kuuluvatest afiksaaladverbidest, nt on üheks verbiks loetud põgenema (selle alla kuuluvad ka välja põgenema, ära põgenema), samuti raputama (sh alla raputama, maha raputama). Arvesse on võetud nii transitiivsed kui ka intransitiivsed verbid. Transitiivsete verbide puhul: 
a) liigutab entiteeti keegi teine (LIIGUTAJA), LIIKUJA ise on LIIGUTATAV, mis vahetab oma asukohta (7) või säilitab oma asukoha TAUSTA suhtes, kuid muudab asendit (8):

(7) Poiss võttis Kroksi kätte ... (L2)

(8) Järsku aga pööras Polla pea suure puurondi poole ... (L1 eesti)

b) võivad liikuda nii LIIGUTATAV ese kui ka LIIGUTAJA ise, mõlemad vahetavad oma asukohta, nt:

(9) ... ja vihased herilased hakkasid teda taga ajama. (L2)

(10) Ka vapper Pitsu, kes oli peremeest jälitanud ... (L1 eesti)

c) võib liikuda ka ainult LIIKUJA, nt:

(11) Poiss ja koer otsisid konna igal pool - saapa sees, voodi all ja igas nurgas. (L2)

(12) Konna otsiti nii saapa seest kui voodi alt. (L1 eesti)

(13) ... ning piilus siis üle palgi. (L1 eesti)

(14) Vaatasid puutüve taha ... (L2)

Näited 11-14 on liikumise väljendamise seisukohast üsna komplitseeritud, kuna neisse kuuluvate verbide tähenduses liikumine otseselt ei sisaldu. Liikumissündmuste kodeeringutena fikseerimise aluseks on piltidel kujutatava tegevuse dünaamika nii otsima, piiluma kui ka vaatama väljendavad siinses lausekonstruktsioonis ja kogu sündmustiku kontekstis verbi agendina toimiva LIIKUJA liikumist TAUSTA suhtes.

Intransitiivsete verbide puhul liigub grammatilise subjektina väljendatud entiteet ise ning vahetab liikumissündmuse käigus oma asukohta (näited 15 ja 16) või säilitab liikudes oma põhilise asukoha TAUSTA suhtes (näited 17 ja 18).

(15) Sealt lendasid välja valju suminaga herilased ... (L2)

(16) Edasi tõttasid Mart ja Muri aknale. (L1 eesti)

(17) ... mille ümber tiirles parv sumisevaid mesilasi. (L1 eesti) 
(18) ... kui noor ja uljas koer mesitaru ümber hüples. (L1 eesti)

Viimased näited, milles liikumissündmuses osalev keha säilitab TAUSTA suhtes oma põhilise asukoha, on pärit eesti üliõpilaste tekstidest, vene üliõpilaste eestikeelsetes kirjutistes puuduvad sellised liikumise kirjeldused täiesti. Põhjuseks on ilmselt õppijakeele sõnavara piiratus, mitte soovimatus seda laadi liikumist kirjeldada. Oma emakeeles vene keeles on ka vaadeldav õppijarühm eelnevate näidetega sarnast asukohta säilitavat liikumist kirjeldanud, nt:

(19) Muri tak staratel'no tjavkal i vertelsja na podokonnike ... 'Muri klähvis ja keerles aknalaual nii püüdlikult ...' (L1 vene)

(20) Ščenok že vsjo prygal na derevo ... 'Kutsikas muudkui hüppas puu najale ...' (L1 vene)

(21) ... i malen'kie ljagušatki rezvilis' rjadom ... '... ja väikesed konnapojad hullasid kõrval...'(L1 vene)

Esitatud andmete kohaselt on niisiis liikumissündmuste kodeeringute hulk L1- ja L2- kõnelejate narratiivides võrreldav, kuid emakeelekõnelejate kasutatud eri verbide hulk peaaegu kaks korda suurem. Järgnevalt vajabki väljaselgitamist, milliseid verbe on õppijad liikumissündmuste väljendamisel eelistanud.

Kuna liikumissündmuste kodeeringuid on õppijate tekstides enam-vähem samal hulgal kui emakeelekõnelejate tekstides, on ilmne, et õppijad ei ole üritanud liikumisnarratiivi etappe vältida ning suhtlusstrateegiate hulka kuuluvat vältimisstrateegiat liikumise üldisel kirjeldamisel ei ole rakendatud. Küll on aga piltidel toimuva edasiandmiseks kasutatud just neid sõnavaralisi ja grammatilisi vahendeid, milles õppijad on ennast kindlamalt tundnud. 
Tabel 1. Liikumise väljendamisel kasutatud sagedasemad verbid eestikeelsetes narratiivides.

\begin{tabular}{|c|c|c|}
\hline Verb & L2-kõnelejad & \begin{tabular}{|c|} 
L1-kõnelejad \\
\end{tabular} \\
\hline minema & $\begin{array}{l}61 \text { (sh minema + edasi, } \\
+ \text { eemale, }+ \text { minema, }+ \\
\text { tagasi, + välja, + ära) }\end{array}$ & $\begin{array}{l}31 \text { (sh minema + edasi, } \\
+ \text { eemale, + minema, } \\
+ \text { ära) }\end{array}$ \\
\hline tulema & $\begin{array}{l}33 \text { (sh tulema }+ \text { juurde, } \\
+ \text { kohal, + välja) }\end{array}$ & 14 (sh tulema + välja) \\
\hline võtma & $\begin{array}{l}19 \text { (sh võtma + kaasa, + } \\
\text { üles, + ära) }\end{array}$ & 12 (sh võtma + kaasa) \\
\hline panema & 9 & 4 \\
\hline
\end{tabular}

Tabel 1 sisaldab andmeid sagedasemate intransitiivsete (minema, tulema) ja transitiivsete (võtma, panema) liikumisverbide kohta. Silma torkab ainult LIIKUMIST, mitte LIIKUMISVIISI väljendavate põhiliikumisverbide minema ja tulema väga sagedane kasutus õppijate tekstides, neid esines ligi kaks korda rohkem kui L1 tekstides. Ka L2 narratiivide liikumissündmuste kirjeldamisel kõige rohkem kasutatud transitiivsed verbid võtma ja panema väljendavad ainult eseme liigutamist, liigutamise viisi täpsustamata. Sagedane verbitüve kasutus toob kaasa ka selle juurde kuuluvate afiksaaladverbide rohkuse. Tabelist 1 paistab, et panema esines ainult üksikverbina, kuid ülejäänud nii üksikkui ühendverbina, kusjuures L2 narratiivides kasutati erinevaid afiksaaladverbe rohkem kui L1 tekstides. Ainult L2 narratiivides esinesid välja minema, juurde tulema, kohal tulema, üles võtma ja ära võtma (näited 22-26).

(22) ... konn läks salajasti purgist välja. (L2)

(23) Ta tuli sinna juurde ... (L2) (pro tuli v jõudis sinna v selle juurde)

(24) Kohal tulles ... (L2) (pro kohale jõudes)

(25) Hirv võttis pea üles ... (L2) (pro tõstis pea üles)

(26) Suur roheline konn lasi Taneli üht väikset konnakest endaga kaasa ära võtma. (L2) (pro kaasa võtta) 
Näidetes 23-26 erineb nii verbi- kui ka afiksaaladverbide kasutus sihtkeelepärasest. Nende näidete verbikasutuses paistab silma tuttavate, üldise tähendusega tuumverbide (Tragel 2003) kasutamine täpsema väljendusvõimaluse asemel, nt tuli sinna juurde, võttis pea üles (vrd jõudis sinna, tõstis pea üles).

Materjali analüüs näitab, et üks vaadeldavate õppijate strateegiaid liikumissündmuste väljendamisel ongi selliste neile tuttavate tuumverbide kasutamine, mis väljendavad ainult liikumist või liigutamist, kuid milles ei sisaldu informatsiooni täpsema liikumisviisi või põhjuse kohta. Niisugune verbikasutus võimaldab õppijatel pildiseerial kujutatud tegevuse dünaamikat edasi anda ning täita neile antud ülesannet - kirjutada seotud tekst, kirjeldades võimalikult paljusid pilte ja kasutades etteantud nimisõnu. Tegemist on õppijate poolt sageli rakendatava üldistamisstrateegiaga - tuttavaid leksikaalseid vahendeid püütakse kasutada väga erinevates situatsioonides, mil olemasolevatest keelelistest ressurssidest ei piisa täpsema väljenduse jaoks. Keele produtseerimisel tuttavate, õppijates kindlustunnet tekitavate sõnade tarvitamist on Angela Hasselgren (1994) nimetanud „leksikaalsete kaisukarude” (ingl lexical teddy bears) kasutamiseks, mis mitme sõnasagedusuuringu kohaselt võib isegi väga edasijõudnud tasemel viia üldise tähendusega sõnade ja väljendite ületarvitamise ning vastavalt spetsiifilisemate, emakeelekõnelejate poolt eelistatud väljendite alatarvitamiseni (vt Ringbom 2007: 101).

Samas ei saa siiski väita, et L2 narratiivides LIIKUMIST ja LIIKUMISVIISI ühendavaid verbe üldse ei esinenud. Õppijate narratiivides oli kasutatud nt verbe hiilima, hüppama, jooksma, kukkuma, lendama, plehku panema, põgenema, ronima, roomama, ruttama, suunduma, sööstma, tormama, viskama jm. Eestlaste rühma tekstides esinesid näiteks hiilima, hulpima, hüplema, jalga laskma, kalpsama, kukkuma, kõõluma, lipsama, luusima, nuuskima, platserdama, potsatama, prantsatama, päkkadele valu andma, suplema, suskama, tiirlema, turnima, upitama jne. Õppijate verbikasutuses puuduvad deskriptiivverbid (L1 tekstides nt kalpsama, platserdama, potsatama, prantsatama), kuid venekeelsetes narratiivides oli mõningaid deskriptiivverbe siiski 
kasutatud (nt pljuxnut'sja 'plartsatama'). Teises keeles on väljendusvahendeid paratamatult vähem kui emakeeles ning sõnavara areneb pidevalt. Deskriptiivse sõnavara omandamine on keeleõppijate jaoks keeruline, kuna deskriptiivseid sõnu kasutatakse vähe ning need on väga tugevasti kontekstiga seotud. Sirje Rammo (2007) uurimuse kohaselt on eesti keele deskriptiivverbid teise keele õppijate jaoks leksikonisõnad, mis omandatakse sõnatasandil kollokatsioonide kaudu ning mida õppijad üldiselt ise loovalt ei moodusta.

L2 narratiivides tuli ette ka mittesihtkeelepärast liikumisverbide kasutust. Näiteks võiks järgmisi näitelauseid üksiklausetena pidada eesti keeles verbikasutuse poolest vastuvõetavateks, kuid laiemat konteksti arvestades on valitud siiski lausesse sobimatud verbid.

(27) ... ning poiss koeraga käisid metsas. (L2) (pro läksid metsa)

(28) ... konn otsustas ära käia ... (L2) (pro ära minna v põgeneda)

(29) ... ning herilased jälgisid neljakäpulist kurjategijat. (L2) (pro jälitasid)

Veaanalüüsi traditsioonide kohaselt on näidetes 27-29 tegemist verbikasutuse varjatud vigadega, mille puhul on lause küll õigesti moodustatud, kuid ei tähenda seda, mida õppija on tahtnud öelda (James 1998: 68). Järgmistes näidetes on verbikasutusvead ilmsemad ning nähtavad ka üksiklausetes.

(30) Järsaku ees hirv hakkas seisma. (L2) (pro jäi seisma)

(31) ... siis poiss võttis konnakese, istutas ta oma pihku ... (L2) (pro pani istuma)

(32) Pois edasi otsustas kivi peale tõusta. (L2) (pro ronida)

(33) ... ning nad koos astusid pikale teele koju. (L2) (pro asusid) 


\subsection{Verbisatelliitide kasutamine L2 narratiivides}

Järgnevad näited illustreerivad verbisatelliitide tüpoloogiliselt lähedast kasutust eesti ja vene keeles.

(34) ... siis tuli august välja ümiseja ... (L2)

(35) ... no iz norki vyskočil zloi xorëk '... aga august hüppas välja kuri tuhkur ...' (L1 vene)

Eestikeelses näites 34 väljendab liikumise TEED afiksaaladverb välja, venekeelses (35) verbiprefiks vy-. Erinevused õppijate lähte- ja sihtkeele vahel ei ole seega eriti suured (võrreldes näiteks juhtumitega, kui lähtekeel kuulub satelliidi-, sihtkeel aga verbikeelte hulka, vt Cadierno 2004). Käesoleva uurimuse seisukohast pakub huvi eelkõige vene emakeelega õppijate poolt eestikeelsetes tekstides kasutatud erinevate afiksaaladverbide hulk, nende kasutuse iseärasused ning võimalikud erinevused eesti ja vene rühma eestikeelsetes narratiivides. ${ }^{5}$ Tabelis 2 on ära toodud kõik verbid, millega koos eesti keele afiksaaladverbe kasutati, igale verbile on lisatud kõik sellega koos kasutatud afiksaaladverbid. Verbid on tähestikulises järjestuses.

Tabel 2. Verbid koos satelliitidega L2 ja L1 eestikeelsetes narratiivides.

\begin{tabular}{|l|l|}
\hline $\begin{array}{l}\text { L2 narratiivide verbid ja verbi- } \\
\text { satelliidid }\end{array}$ & $\begin{array}{l}\text { L1 narratiivide verbid ja verbi- } \\
\text { satelliidid }\end{array}$ \\
\hline ajama (+ taga) & $\begin{array}{l}\text { ajama (+ minema, + taga, + välja) } \\
\text { ehmatama (+ alla) } \\
\text { hiilima (+ minema, + välja) } \\
\text { hüppama (+ välja, + ära) } \\
\text { ilmuma (+ välja) } \\
\text { jooksma (+ kaasa, + minema, + } \\
\text { tagasi, + ära) }\end{array}$ \\
$\begin{array}{l}\text { hüppama (+ järele, + välja) } \\
\text { jlmuma (+ välja) }\end{array}$ \\
\hline
\end{tabular}

5 Afiksaaladverbid moodustavad koos verbiga ühtse terviku - ühendverbi. Afiksaaladverbina käituvad sõnad võivad esineda ka iseseisvate adverbidena või kaassõnadena (vt EKG I 1995: 33) . 


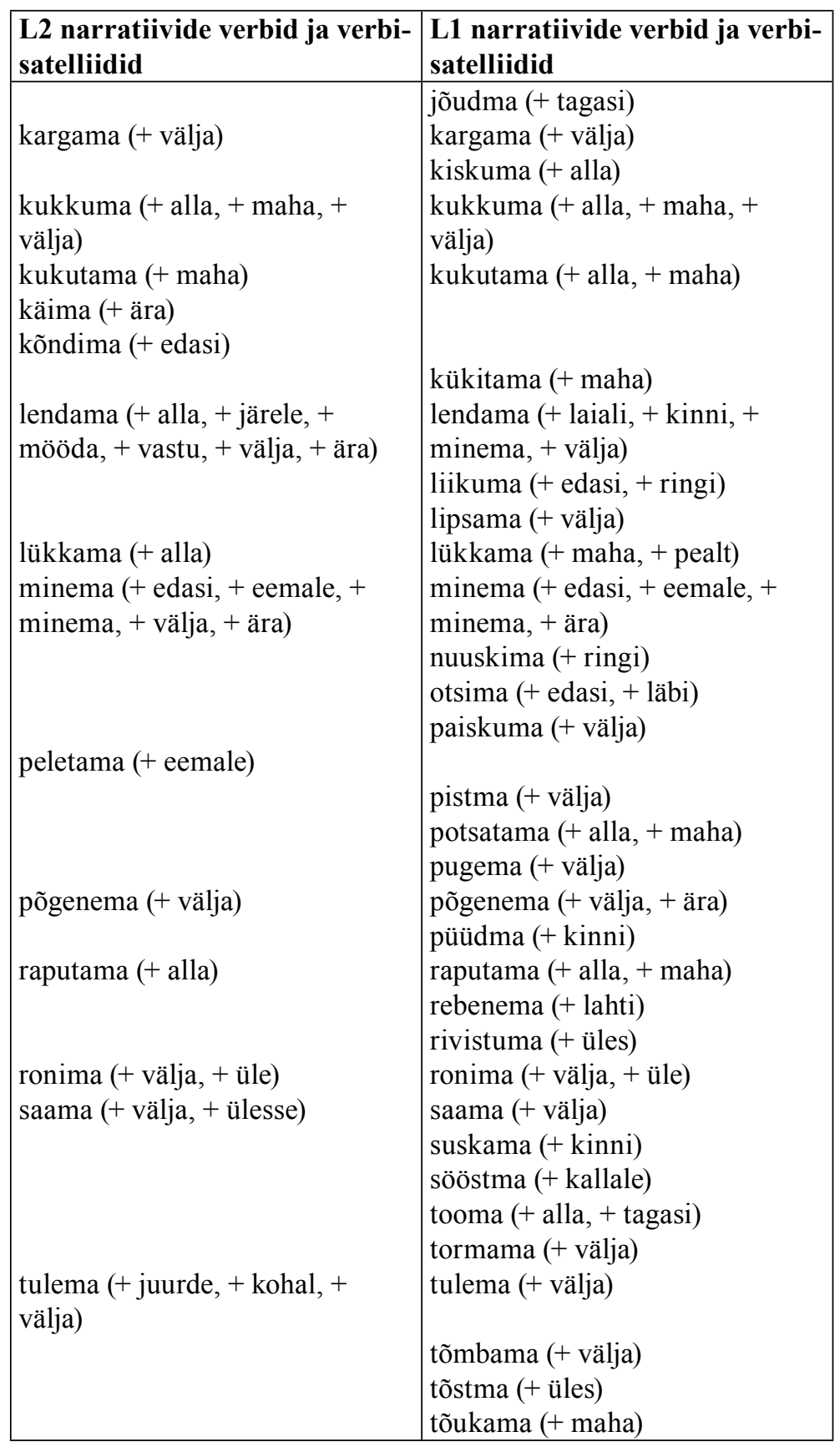




\begin{tabular}{|l|l|}
\hline $\begin{array}{l}\text { L2 narratiivide verbid ja verbi- } \\
\text { satelliidid }\end{array}$ & $\begin{array}{l}\text { L1 narratiivide verbid ja verbi- } \\
\text { satelliidid }\end{array}$ \\
\hline tõusma (+ püsti) & $\begin{array}{l}\text { tõusma (+ üles) } \\
\text { vaatama (+ läbi) }\end{array}$ \\
varastama (+ ära) & $\begin{array}{l}\text { veerema (+ alla) } \\
\text { viima (+ edasi, }+ \text { ära) } \\
\text { viskama (+ alla) } \\
\text { võtma (+ kaasa) }\end{array}$ \\
$\begin{array}{l}\text { viskama (+ alla, + välja) } \\
\text { võtma (+ kaasa, + üles, + ära) }\end{array}$ & Kokku 43 eri verbi \\
\hline Kokku 22 eri verbi &
\end{tabular}

Vene emakeelega õppijarühma ja eestlastest võrdlusrühma narratiivides liikumissündmuste kirjeldamisel kasutatud afiksaaladverbide mitmekesisusest ja kasutussagedusest annab ülevaate tabel 3, kus on esitatud ühendverbide koosseisu kuuluvad afiksaaladverbid esinemissageduse järjekorras.

Tabel 3. Afiksaaladverbid L2 ja L1 narratiivide liikumissündmuste kirjeldustes.

\begin{tabular}{|l|l|}
\hline $\begin{array}{l}\text { L2 narratiivide afiksaaladver- } \\
\text { bid (23 erinevat) }\end{array}$ & $\begin{array}{l}\text { L1 narratiivide afiksaaladver- } \\
\text { bid (20 erinevat) }\end{array}$ \\
\hline välja 65 & välja 51 \\
\hline maha 21 & alla 31 \\
\hline alla 11 & maha 8 \\
\hline ära 11 & ära 8 \\
\hline taga 5 & läbi 5 \\
\hline kaasa 4 & minema 5 \\
\hline edasi 3 & taga 5 \\
\hline järele 3 & edasi 4 \\
\hline eemale 2 & kaasa 4 \\
\hline järgi 2 & kinni 3 \\
\hline püsti 2 & ringi 2 \\
\hline $\begin{array}{l}\text { juurde, kinni, kohal, minema, } \\
\text { mööda, otsa, sisse, tagasi, vastu, } \\
\text { üle, üles, ülesse 1 }\end{array}$ & $\begin{array}{l}\text { eemale, järgi, kallale, lahti, laiali, } \\
\text { pealt, tagasi, üle, üles 1 }\end{array}$ \\
\hline
\end{tabular}

Afiksaaladverbide välja, alla ja maha suur esinemissagedus tuleneb pildiseerial kujutatud tegevusest - väljapoole ja 
allapoole suunatud liikumist oli piltidel kujutatud rohkesti ning see tingis ka tekstides liikumise kirjeldamisel TEE väljendamiseks kasutatud satelliitide valiku. Eesti keele afiksaaladverbidele ei vasta vene keeles alati verbiprefiks, mõnikord väljendab vene keeles sama funktsiooni ka noomeni käändevorm või adverb, nt allapoole toimuva liikumise kirjeldamisel, vrd vn upal na zemlju - ee kukkus maha, vn poletel vniz - ee lendas alla. Sellised juhtumid on siinse uurimuse vene emakeelega õppijarühma jaoks selged. Väljapoole toimuva liikumise kirjeldamisel kasutatud afiksaaladverb välja on funktsionaalselt sarnane vene keele verbiprefiksiga $v y$-, mida õppijad kasutasid venekeelsetes tekstides nt verbides vytaščit' 'välja tõmbama', vylezat' 'välja ronima', vyletat' 'välja lendama', vybrat'sja 'välja pääsema', vyvalit'sja 'välja kukkuma', vyxodit' 'välja tulema', vypadat' 'välja kukkuma', vyprygnut' 'välja hüppama' jt. Sarnasus lähte- ja sihtkeele vahel ning emakeelele toetumise võimalus on ilmselt üheks põhjuseks, miks välja tarvitamine oli L2 ja L1 narratiivides väga sarnane. Õppijarühma tekstides esines ainult üks afiksaaladverbi välja mittesihtkeelepärane kasutusjuht (näide 34) ning ühel juhul oli jäetud välja lauses eksplitsiitselt väljendamata (näide 35$)^{6}$, muudel juhtudel sarnanes välja kasutus L1 materjaliga (nt näited 36, 37).

(34) Lõppude lõpuks viskas hirv poissi järsakust välja ... (L2) (pro järsakust alla)

(35) Ootamatult koer kukkus aknast, purk läks katki ja tema pea oli jälle vaba. (L2) (pro kukkus aknast välja v alla)

(36) ... kuid sealt hüppas välja väike ümiseja ... (L2)

(37) ... nii kukkus ta purgiga aknast välja. (L2)

Ka muude afiksaaladverbide kasutus oli L2 ja L1 rühma narratiivides väga sarnane. Õppijate tekstides esines vaid üksikuid sihtkeele seisukohast ebasobivaid afiksaaladverbide kasutusjuhte (näited 38-40). Näidetes 38 ja 39 on sulandunud

6 Seda näidet ei ole tabelis 3 sisalduvate arvuliste andmete hulka arvatud, kuna afiksaaladverb puudus. Küll aga on seda näidet arvestatud liikumissündmuste kodeeringute arvestuses. 
satelliidi- ja verbikasutuse probleem, näites 40 aga esineb õppijatele ilmselt emakeelekõnelejate suulisest kõnest tuttavaks saanud argikeelne afiksaaladverb ülesse (L1 rühma narratiivides seda ei esinenud)

(38) ... konn läks aknast ära. (L2) (pro aknast välja v põgenes akna kaudu)

(39) Kohal tulles ... (L2) (pro kohale jõudes)

(40) Kui nad puuronti ülesse said nägid nad ... (L2) (pro üles said)

Muudel juhtudel L2 ja L1 rühma verbisatelliidikasutus ei erinenud. Sarnaselt emakeelekõnelejatega kasutasid ka keeleõppijad afiksaaladverbe nii transitiivsete (näide 41) kui intransitiivsete verbidega (näide 42).

(41) Koer oli samal ajal herilasepesa puust alla raputanud. (L2)

(42) Ronisid sellest üle ... (L2)

Erinevus vene ja eesti rühma tulemuste vahel on eelkõige verbitüvede kasutuses. Õppijate tekstides oli afiksaaladverbe kasutatud koos 22 eri verbiga, L1 tekstides aga koos 43 eri verbiga. Verbisatelliitide kasutamine vaadeldavale õppijarühmale üldiselt probleeme ei valmista ning hea soorituse taustaks võib vähemalt osaliselt olla toetumine vene keele verbiprefiksite analoogiale ning positiivne ülekanne emakeelest õppijakeelde.

\subsection{LÄнTE- ja SIHTKонА ühendamine ühe lii- kumissündmuse kirjelduses}

Artiklis kirjeldatava uurimuse üheks eesmärgiks on välja selgitada, kas õppijate narratiivides on LÄHTE- ja SIHTKOHA väljendamisel emakeelekõnelejatega võrreldes erinevusi ja kui on, siis milles need seisnevad. Analüüsimiseks on valitud pildiseeria üks pilt, nn järsakustseen, ning vaadeldakse, kuidas on kahe 
uurimuses osalenud rühma tekstides väljendatud selles stseenis kujutatud liikumine. Pildil on hirv, poiss ja koer; hirv on jõudnud järsakuni ja viskab poisi järsakust alla või kukub poiss ise alla, koer temaga koos, all on mingi veekogu.

Kirjeldatud pilt sobib LÄHTE- ja sІнтконA väljendamise uurimiseks seetõttu, et tegemist on narratiivi süžees olulise stseeniga, mida kõik uurimuses osalejad on pikemalt või lühemalt kirjeldanud ning milles LÄHTE- ja SIнтконт on jutustuse edasiandmise juures võrdselt olulised. Sama stseeni on tüpoloogiliselt erinevate keelte esimese keelena omandamise alases uurimuses analüüsinud ka R. Berman ja D. Slobin (1994), kes lähtusid sellest, kas liikumise lähte- ja sihtkohta väljendatakse erinevates osalausetes ja jagatakse seega mitme liikumissündmuse kirjelduse vahel või ühendatakse need ühe ja sama liikumissündmuse kirjeldusse ehk rakendatakse sündmuste sulandumist (ingl event conflation). Teise keele omandamise alal on järsakustseeni kirjeldamist samadest põhimõtetest lähtudes analüüsinud T. Cadierno (2004).

Terve järsakustseeni kirjeldamiseks on käesolevas uurimuses osalejatel tavaliselt olnud vaja väljendada rohkem kui üht liikumissündmust, millest üks võib sisaldada liikumise LÄHTEконтА, teine SIнтконтА, näiteks:

(43) Hirv oli väga kuri poisi peale ja viis teda järsule ja viskas teda sealt alla. Poiss ja koer kukusid tiiki. (L2)

Näites 43 on väljendatud kolme liikumissündmust (viis teda järsule (pro järsakule), viskas teda sealt alla, poiss ja koer kukusid (pro kukkusid) tiiki), millest kahes on väljendatud liikumise sінтконт (järsule, tiiki), ühes цӓнтеконт (sealt). Huvipakkuv on aga küsimus, kuivõrd sisaldub nii LÄHTE- kui ka SIнтконт ühe liikumissündmuse kirjelduses, ehk kas ja mil määral on keeleõppijad võrreldes emakeelekõnelejatega kasutanud sündmuste sulandumist.

Järsakustseeni kirjeldamisel paistab silma, et sündmuste sulandumine ehk lähte- ja sihtkoha liitmine ühe liikumissündmuse kirjeldusse iseloomustab eelkõige õppijarühma kirjutisi, 
eesti üliõpilased seevastu eelistasid pikemat väljendusviisi ning kirjeldasid lähtekohta ja sihtkohta enamjaolt erinevate liikumissündmuste komponendina.

Lähte- ja sihtkoht esinesid ühe ja sama liikumissündmuse komponentidena L2 narratiivides 10 korda (näited 44 ja 45), L1 materjalis 5 korda (näited 46 ja 47).

(44) Ta võttis poissi oma sarvedele ja viskas teda järsakult tiiki. (L2)

(45) Hirmunud hirv jooksis järsaku juurde ning peatselt kukkusid Tomi ja Pontu järsaku servalt otse vette. Sulpsti! (L2)

(46) Hirv jäi seisma täpselt kallaku serval, Oskar ja Polla pillati järsaku servast alla tiiki. Plärts! (L1 eesti)

(47) Sealt prantsatas marakratt otse vette, hirmunud Pontu aga püüdis kõigest väest kuivaks jääda. (L1 eesti)

L2 narratiivid erinevad selle stseeni osas seega L1 tekstidest liikumise lähte- ja sihtkoha kompaktsema väljendusviisi poolest. Põhjuste otsimisel tuleks vaadata ka järsakustseeni kirjeldamist õppijate emakeeles. Vene keeles on lähte- ja sihtkoha väljendamine ühe ja sama liikumissündmuse kirjeldamisel samuti võimalik ning käesoleva uurimuse venekeelses materjalis oli sellist väljendusviisi kasutatud viiel korral (nagu ka emakeelsete eestlaste tekstides), nt:

(48) Los' okazalas' nedobroželatel'nym i skinul našix druzei s obryva prjamo v ručei. 'Põder osutus ebasõbralikuks ja lükkas meie sõbrad järsakult otse ojja.' (L1 vene)

(49) ... i mal'čik vmeste s sobakoi kubarem poleteli s vysokogo berega $\mathrm{v}$ prud. '... ja poiss lendas koos koeraga ülepeakaela kõrgelt kaldalt tiiki.' (L1 vene)

Kuigi õppijate emakeeles on lähte- ja sihtkoha ühendamine ühe liikumissündmuse kirjeldusse loomulik, oli siinse uurimuse venekeelsetes narratiivides tavalisem lähte- ja sihtkoha paigutamine eri liikumissündmuste kirjeldustesse nagu ka emakeelsete eestlaste tekstides, nt: 
(50) Los' skinul mal'čika i psa s obryva i oni upali v prud. 'Põder lükkas poisi ja koera järsakust alla ja nad kukkusid tiiki.' (L1 vene)

Näites 50 on kaks liikumissündmuse kodeeringut, millest esimeses on väljendatud liikumise lähtekoht (Los' skinul mal'čika i psa s obryva 'Põder lükkas poisi ja koera järsakust alla'), teises sihtkoht (oni upali v prud 'nad kukkusid tiiki'). Seega on õppijatel olnud võimalik järsakustseeni kirjeldamisel emakeelele toetuda. Arvestades venekeelsetes tekstides esinenud sündmuste sulandumise vähesust, ei ole rohket sündmuste sulandumist järsakustseenis L2 narratiivides põhjust pidada õppijate emakeelest tulenevaks väljendusviisiks, pigem on siin tegemist õppijakeele eripäraga.

Tüpoloogiliselt erinevate keelte esimese keele omandamise alases laiaulatuslikus uurimuses on R. Berman ja D. Slobin (1994: 118, 163-164) näidanud, et eespool kirjeldatud sündmuste sulandumine (vt näited 44-49) liikumissündmuste kirjeldamisel on iseloomulik eelkõige satelliidikeeltele, millele on ühtviisi omane ka sündmuste serialiseerimine ehk lähte- ja sihtkoha väljendamine eri osalausetes (vt näited 43 ja 50), verbikeeltes seevastu sündmuste sulandumist peaaegu ei kasutata. Eesti ja vene keel on satelliidikeeled ning siin käsitletud mõlema keele L1 materjalis esines Bermani ja Slobini järgi satelliidikeeltele omast sündmuste sulandumist ja ka serialiseerimist, kuid domineeris viimane väljendusviis ehk liikumise lähte- ja sihtkoha paigutamine eri liikumissündmuste kirjeldustesse. Nii eestikui ka venekeelses L1 materjalis oli 21 tekstist viies kasutatud järsakustseeni kirjeldamisel sündmuste sulandumist, ülejäänud juhtudel serialiseerimist või oli jäetud kas lähte- või sihtkoht väljendamata.

Järsakustseeni kirjeldamisel väljendusid seega kõige komplekssemalt keeleõppijad. Tulemus on huvipakkuv, sest lähte- ja sihtkoha väljendamine kontsentreeritult ühe liikumissündmuse kirjelduses on keerulisem kui kahte eri liikumissündmusse jagamine või ka variant, et väljendatakse näiteks ainult sihtkohta, aga lähtekohta üldse mitte. Õppijad on seega valinud eesti keeles kee- 
rulisema ja samal ajal ka ökonoomsema väljendusviisi kui oma emakeeles. Üheks põhjuseks võib olla keeleõppijatele omane korrektsusetaotlus. Õppijate keelekasutust võib mõnevõrra olla mõjutanud ka sõnaloendi etteandmine: kuna sõnaloendis olid ära toodud sõnad hirv, järsak (kõrge kallas) ja tiik, püüdsid töökäsku järgivad keeleõppijad neid sõnu ka oma jutustuses kasutada. Eesti üliõpilastel sõnaloendit ees ei olnud, nad nimetasid küll samu objekte, kuid mitte nii järjekindlalt (nt järsakut vms nimetati L1 tekstides 14 korral, L2 tekstides aga 21 korral ehk kõigis kirjutistes).

\subsection{Suhtlusstrateegiate rakendamine liikumis- sündmuste väljendamisel}

Käesolevas uurimuses osalenud vene emakeelega eesti keele õppijate tekstides esines liikumissündmuste kodeeringuid, mille puhul paistab olevat rakendatud spetsiifilisi, keeleliste ressursside nappusest põhjustatud suhtlusstrateegiaid (vt nt Tarone 1983, Dörnyei ja Scott 1997, Dörnyei ja Kormos 1998, Hennoste ja Vihalemm 1999). Kuna siinse uurimusega ei kaasnenud retrospektiivsed intervjuud, pole õppijate endi selgitusi võimalik kasutada. Näited on valitud artikli autorite arvamusest lähtudes, arvestades tekste tervikuna ning samade situatsioonide kirjeldusi õppijate emakeelsetes narratiivides. Liikumist ei ole neis näidetes edasi antud otseselt liikumist või liigutamist väljendavate verbide abil, vaid kaudsete vahenditega, seega võib eeldada, et kirjutajatel oli eesti keeles väljendamine takistatud ja kasutati ümberütlemisstrateegiat.

Ümberütlemisstrateegia rakendamise näiteid esineb kolme pildiseerias kujutatud situatsiooni kirjeldamisel. Situatsiooni, milles hirv võtab poisi oma sarvedele, kirjeldati kahel juhul ümberütlevalt, staatilise verbi olema abil (näited 51 ja 52).

(51) ... ning hetke pärast oli Tomi juba hirve suure sarvedel. (L2)

(52) ... ja Tanel, kelle kätes olid sarved, oli ka hirve suure peal. (L2) 
Olema-verbi kasutamine on selle situatsiooni kirjeldamisel erandlik, kuna muudel juhtudel kasutati keha liigutamist või liikumist otseselt väljendavaid verbe võtma, viskama, sattuma, kukkuma (näited 53 ja 54).

(53) Suur kuri metshirv võttis poisi oma sarvede peale ... (L2)

(54) Poiss kukkus tema pähe. (L2)

Ka venekeelsetes narratiivides ei esinenud näidetega 51 ja 52 sarnanevaid liikumissündmuste kodeeringuid, vaid poisi sattumist hirve sarvedele väljendati liigutamise ja liikumise otsese kirjeldamisega (näited 55 ja 56), samamoodi oli ka eesti üliõpilaste tekstides (näited 57 ja 58).

(55) Los' podbrosil mal'čika sebe na roga ... 'Põder haaras poisi endale sarvedele ...' (L1 vene)

(56) ... kak zalez na emu golovu ... '... kui oli talle pähe roninud ...' (L1 vene)

(57) ... märkamatult haarab kivi taga seisnud hirv ta sarvede peale ... (L1 eesti)

(58) ... kukkus ta põdra sarvede vahele. (L1 eesti)

Situatsiooni, milles koer liigub poissi kandva hirve kõrval, väljendati ühel juhul ümberütlevalt, kasutades selleks samuti staatilist olema-verbi (näide 59).

(59) ... koer oli hirve kõrval ning valjusti haugus. (L2)

Eelnevat näidet võib ümberütleva suhtlusstrateegia rakendamiseks pidada seetõttu, et pildil on koera liikumine selgelt jooksmisena identifitseeritav ning kõigil muudel juhtudel kasutati selle situatsiooni kirjeldamisel liikumisverbe, seda nii L2 tekstides (näited 60 ja 61) kui ka venekeelsetes tekstides (näited 62 ja 63).

(60) Koer haukudes jooksis kõrval. (L2)

(61) ... Pontu jooksis kõrval. (L2) 
(62) Bežal s nimi i Šarik. 'Ka Šarik jooksis nendega koos.' (L1 vene)

(63) Rjadom nëssja pës ... 'Kõrval kihutas koer ...' (L1 vene)

Kolmas situatsioon, mille kirjeldamisel üks ümberütlemisstrateegiana käsitletav näide esines, kujutab koera, kes hüppab puu otsas rippuva herilasepesa all, püüdes seda alla raputada. Näide 64 on selle situatsiooni ümberütlev kirjeldus L2 materjalist, milles liikumist on väljendatud üldise tähendusega transitiivse verbi tegema abil.

(64) Koer tegi kõike ja kõigest väest, et herilasepesa kukuks. (L2)

Muudel juhtudel kasutasid keeleõppijad selle sündmuse kirjeldamisel eseme liigutamist väljendavaid verbe, nt raputama ja kukutama (näited 65 ja 66) ning ka venekeelsetes narratiivides kasutati selle situatsiooni kirjeldamisel liigutamise viisi täpsemalt väljendavaid tegusõnu, nt sbit' 'alla lööma', uronit' 'alla kukutama' (näited 67 ja 68).

(65) Koer oli samal ajal herilasepesa puust alla raputanud. (L2)

(66) Samaks ajaks koer jõudis juba herilasepesa maha kukutada. (L2)

(67) ... a ego sobačka tem vremenem sbila ulei s vetki ... '... aga tema koer lõi samal ajal mesilasepesa oksalt alla ...' (L1 vene)

(68) Pës uronil ulei ... 'Koer kukutas mesilasepesa alla ...' (L1 vene)

Eestlastest võrdlusrühma narratiivides seesuguseid kaudseid liikumise kirjeldusi ei esine ning ka keeleõppijate tekstides oli otseselt ümberütlemisena käsitletavaid liikumissündmuste kodeeringuid materjali tervikhulka arvestades väga vähe. See annab tunnistust vaadeldava õppijarühma oskusest oma olemasolevaid leksikaalseid ja grammatilisi vahendeid lii- 
kumissündmuste kirjeldamisel eesmärgi- ja sihtkeelepäraselt ära kasutada.

\section{Kokkuvõtteks}

Artiklis käsitleti liikumissündmuste väljendamise eripära õppijakeeles olukorras, kus teise keele õppijate emakeel (vene keel) ja sihtkeel (eesti keel) kuuluvad L. Talmy liigituse järgi tüpoloogiliselt sarnasesse satelliidikeelte klassi, kuid verbisatelliitide olemus ja paiknemine on erinev. Kuna senised teise keele liikumissündmuste uurimused on keskendunud tüpoloogiliselt täiesti erinevate lähte- ja sihtkeeltega õppijakeelte analüüsimisele (vt Cadierno 2004, Cadierno ja Ruiz 2006), täiendab siinne käsitlus seda uurimisvaldkonda just tüpoloogiliselt lähedaste lähte- ja sihtkeelega õppijakeele tulemuste osas. Artiklis käsitlesime vene emakeelega edasijõudnud eesti keele õppijate (B2-tase) kirjalikes narratiivides sisaldunud liikumissündmusi, võrrelduna emakeelsete eestlaste samalaadse keeleainesega.

Uurimuses osalenud vene emakeelega õppijad on pildiseeria kirjeldamisel lähtunud neile antud ülesandest ning kirjutanud sisult terviklikud narratiivid. Kuna piltidel kirjeldatud sündmuste edasiandmisel on vältimatult vajalik korduvalt väljendada erinevat liikumist, on M. Mayeri pildiseeria kasutamine materjali kogumise stiimulina ennast õigustanud: liikumisnarratiivi etappide kirjeldamist õppijad ei väldi, seda kinnitab ka liikumissündmuste kodeeringute sarnane keskmine hulk võrreldes emakeelekõnelejate analoogiliste narratiividega. Vaadeldava õppijarühma narratiivides sisalduvaid liikumissündmuste kirjeldusi eristab eesti võrdlusrühma keeleainesest peamiselt verbikasutus - õppijad kasutasid liikumise kirjeldamisel umbes kaks korda vähem erinevaid verbe kui emakeelekõnelejad, seejuures puudusid täiesti deskriptiivverbid. Õppijarühma verbikasutuse eripäraks on ainult liikumist, kuid mitte täpsemat liikumisviisi väljendavate liikumise tuumverbide minema ja tulema väga sage tarvitamine. Sellised tuttavad ja kindlalt omandatud verbid on õppijate jaoks omamoodi turvasõnad (vt Hasselgren 1994), 
mille sage kasutamine vähendab paratamatult muude verbide osakaalu.

Liikumise teed väljendavate afiksaaladverbide kasutamine ei ole vaadeldavatele vene emakeelega õppijatele üldiselt probleemiks, afiksaaladverbe on enamikul juhtudel kasutatud emakeelekõnelejatega sarnaselt. Kuna eesti ja vene keele verbisatelliitide vahel ilmneb funktsionaalne keeltevaheline sarnasus, võib hea soorituse taustaks olla toetumine vene keele verbiprefiksite analoogiale. Saadud tulemus illustreerib positiivse ülekande võimalikkust mittesugulaskeelte puhul situatsioonis, kus lähte- ja sihtkeel on küll mõlemad tüpoloogiliselt satelliidikeeled, kuid satelliitide olemus ja paiknemine on erinev.

Õppijate tekstides esineb emakeelekõnelejatest rohkem sündmuste sulandumist - lähte- ja sihtkoha liitmist ühe ja sama liikumissündmuse kirjeldusse. Seesuguse kompleksse ja samaaegselt ka ökonoomse väljendusviisi põhjuseks on tõenäoliselt keeleõppijatele loomuomane korrektsusetaotlus ning soov kõiki ette antud nimisõnu oma narratiivis kasutada. Liikumissündmuste kirjeldamisel tuleb õppijatel mõnikord ette ka väljendusvahendite nappust, mis kompenseeritakse suhtlusstrateegiate hulka kuuluva ümberütlemisstrateegiaga - sündmustikus olulist tegevust ei jäeta kirjeldamata, vaid valitakse selleks teistsugused keelelised vahendid (liikumisverbi asemel staatiline verb olema või liigutamist täpsemalt väljendavate verbide asemel üldise tähendusega verb tegema).

Siinse artikli tulemused iseloomustavad liikumissündmuste väljendamist ainult ühe venekeelse õppijarühma eestikeelsetes narratiivides. Eesti keele teise keelena omandamise uurimisele seab paratamatult piirid erinevate emakeeltega õppijate vähesus. Keeruline on leida keeleoskustasemelt ja osalejate arvult võrdväärset tüpoloogiliselt erineva emakeelega õppijate gruppi, kelle kõnesooritustega siinseid tulemusi võrrelda. Loodame siiski, et tulevikus on võimalik samasugune uurimus läbi viia ka emakeelena mõnd verbikeelt (nt hispaania keelt) või eesti keelega sarnaselt liikumistee väljendamisel afiksaaladverbe kasutavat satelliidikeelt (nt inglise keelt) kõneleva õppijarühma narratiivide baasil. 


\section{Tänuavaldus}

Uurimust on toetanud sihtfinantseeritav teema SF0180056s08 ja Eesti Teadusfondi grant 9300. Täname kõiki uurimuses osalenud üliõpilasi.

\section{Aadress:}

Raili Pool, Renate Pajusalu

Eesti ja üldkeeleteaduse instituut

Tartu Ülikool

Jakobi 2

51004 Tartu, Eesti

E-mail: raili.pool@ut.ee, renate.pajusalu@ut.ee

\section{Kirjandus}

Berman, Ruth A. and Dan Isaac Slobin (1994) Relating events in narrative: a crosslinguistic developmental study. Hillsdale, New Jersey: Lawrence Erlbaum.

Cadierno, Teresa (2004) "Expressing motion events in a second language: a cognitive typological perspective". In Michel Achard and Susanne Niemeier, eds. Cognitive linguistics, second language acquisition, and foreign language teaching, 13-49. Berlin, New York: Mouton de Gruyter.

Cadierno, Teresa (2008) "Learning to talk about motion in a foreign language". In Peter Robinson and Nick C. Ellis, eds. Handbook of cognitive linguistics and second language acquisition. New York and London: Routledge.

Cadierno, Teresa and Lucas Ruiz (2006) "Motion events in Spanish L2 acquisition". Annual Review of Cognitive Linguistics 4, 183-216.

Dabrowska, Ewa (2004) Language, mind and brain. Edinburgh: Edinburgh University Press.

Dörnyei, Zoltàn and Judit Kormos (1998) "Problem-solving mechanisms in L2 communication. A psycholinguistic perspective". Studies in Second Language Acquisition 20, 349-385.

Dörnyei, Zoltan and Mary Lee Scott (1997) "Communication strategies in a second language: definitions and taxonomies". Language Learning 47, 1, 173-210.

EKG I 1995 = Erelt, Mati, Reet Kasik, Helle Metslang, Henno Rajandi, Kristiina Ross, Henn Saari, Kaja Tael ja Silvi Vare (1995) Eesti keele grammatika I. Morfoloogia. Sõnamoodustus. Tallinn: Eesti Teaduste Akadeemia Eesti Keele Instituut. 
Hasselgren, Angela (1994) "Lexical teddy bears and advanced learners: A study into the ways Norwegian students cope with English vocabulary”. International Journal of Applied Linguistics 4, 237-260.

Hausenberg jt 2008 = Hausenberg, Anu-Reet, Marju Ilves, Annekatrin Kaivapalu, Krista Kerge, Katrin Kern, Mare Kitsnik, Ingrid Krall, Karin Rummo ja Tiina Rüütmaa (koostajad) (2008) Iseseisev keelekasutaja. B1- ja B2-taseme eesti keele oskus. Riiklik Eksami- ja Kvalifikatsioonikeskus.

Hennoste, Tiit ja Triin Vihalemm (1999) „Võõrkeele suhtlusstrateegiad”. Akadeemia 8, 1571-1607.

James, Carl (1998) Errors in language learning and use. Exploring error analysis. Longman and New York: Longman.

Mayer, Mercer (1969) Frog, where are you? New York: Dial Books for Young Readers.

Rammo, Sirje (2007) „Eesti keele sõnatuletussüsteemi omandamisega seotud probleeme". Kogumikus Raili Pool, toim. Emakeel ja teised keeled V, 175-183. (Tartu Ülikooli eesti keele (võõrkeelena) õppetooli toimetised, 6.) Tartu: Tartu Ülikooli Kirjastus.

Ringbom, Håkan (2007) Cross-linguistic similarity in foreign language learning. Clevedon, Buffalo, Toronto: Multilingual Matters Ltd.

Seinberg, Jaana (2011) Eesti keel kui satelliidikeel. Käsikirjaline bakalaureusetöö. Tartu: Tartu Ülikool. Eesti keele osakond.

Slobin, Dan I. (1996a) "From "thought and language" to "thinking for speaking'”'. In John J. Gumperz, ed. Rethinking linguistic relativity, 70-96. Cambridge University Press.

Slobin, Dan I. (1996b) "Two ways to travel: verbs of motion in English and Spanish". In Masayoshi Shibatani and Sandra A. Thompson, eds. Grammatical constructions. Their form and meaning, 195-219. Oxford: Clarendon Press.

Talmy, Leonard (1985) "Lexicalization patterns: Semantic structure in lexical forms". In Timothy Shopen, ed. Language typology and syntactic description. Vol. 3: Grammatical categories and the lexicon. Cambridge: Cambridge University Press.

Talmy, Leonard (2007) "Lexical typologies". In Timothy Shopen, ed. Language typology and syntactic description. Second Edition. Volume III: Grammatical categories and the lexicon, 66-168. Cambridge: Cambridge University Press.

Tarone, Elaine (1983) "Some thoughts on the notion of 'communication strategy". In Claus Færch and Gabriele Casper, eds. Strategies in interlanguage communication, 61-74. London and New York: Longman.

Tragel, Ilona (2003) Eesti keele tuumverbid. (Dissertationes Linguisticae Universitatis Tartuensis, 3.) Tartu: Tartu Ülikooli Kirjastus.

Veismann, Ann ja Ilona Tragel (2008) „Kuidas horisontaalne ja vertikaalne liikumissuund eesti keeles aspektiks kehastuvad". Keel ja Kirjandus 7, 515-530. 


\begin{abstract}
Raili Pool, Renate Pajusalu: Expressing motion events in written narratives of Estonian as a second language. The paper looks at the expression of motion events used by Russian native speakers learning Estonian (B2 language proficiency level) in written narratives. Mayer's (1969) wordless picture book "Frog, where are you?" was used as the stimulus in collecting written narratives produced by 21 students with Russian as their mother tongue and 21 students with Estonian as their mother tongue for comparison. Similar narratives were also collected from the L2 group in their mother tongue, Russian. In analysing the motion events, we proceed from Talmy's (1985, 2007) approach. More specifically, the paper focuses on the verbs and verb satellites used in describing motion events and on expressing the source and target in describing one and the same motion event; the paper also looks at the possibilities of applying the communication strategies in L2 narratives. Based on the linguistic data analysed it can be claimed that L2 subjects do not avoid the stages of the motion narrative; however, they use very often the motion verbs with a general meaning - minema 'to go' and tulema 'to come' - which enable to convey the dynamics of the activity depicted on the pictures, but which do not involve the manner of motion. The use of verb satellites expressing path (in Estonian these are affixal adverbs) does not pose a problem for L2 subjects. Since there is a functional cross-linguistic similarity between the Estonian affixal adverbs and Russian verb prefixes, it is probable that language learners have relied on the analogy of Russian verb prefixes. Characteristic of L2 narratives is also the merging of the source and the target of the motion into one and the same motion event description and the use of the static verb olema 'to be' in describing motion; the latter can be seen as a circumlocution strategy intrinsic to language learners.
\end{abstract}

Keywords: motion event, verb satellites, affixal adverbs, communication strategies, Russian, Estonian 